\title{
The Role of Librarians in the Implementation of Knowledge Management in IPDN Libraries
}

\author{
Delis Sri Maryati ${ }^{1}$, Iim Wasliman ${ }^{2}$, Achmad Mudrikah $^{3}$, R. Supyan Sauri ${ }^{4 *}$ \\ 1) STAI Yapata Al-Jawami Bandung Indonesia. \\ 2,3,4) Universitas Islam Nusantara (UNINUS) Bandung Indonesia \\ *Coresponding Author \\ Email : delis.sri.maryati@gmail.com
}

\begin{abstract}
This research describe about the role of librarians in the implementation of knowledge management in IPDN library. The general purpose of this study was to determine the role of librarians in the implementation of knowledge management in the IPDN Library. This research uses qualitative research with descriptive method. As a result, librarians have implemented knowledge management by means of knowledge identification, knowledge acquisition, knowledge development, knowledge sharing management and knowledge storage.
\end{abstract}

\section{Keywords: Librarian, Knowledge Management.}

\section{INTRODUCTION}

According to Law No. 2 of 1989 concerning the National Education System in article 55 , it is stated that one of the requirements to run a university must have a library. Every university needs a library to achieve its vision and mission in accordance with the Tri Dharma of Higher Education, namely education, research, and community service.

In the Regulation of the Head of the National Library of the Republic of Indonesia Number 13 of 2017 concerning National Standards for Higher Education Libraries to achieve its goals, the university library must fulfill the functions of education, research, information, recreation and preservation.

Government policy, through the national library, has issued these standards with the aim of uniforming definitions, specifications and quality characteristics consisting of the standards of collections owned, standards of existing facilities and infrastructure, standards of services performed, standards of human resources for librarians who run, standards of implementation and library management standards. College library standards are prepared as guidelines for university libraries to promote and maintain the role of university libraries as partners in education, achieve the institution's vision and mission, and position the library as a leader in implementing sustainable quality management.

Since the issuance of the Regulation of the Head of National Library of Indonesia Number 13 of 2017, all university libraries in the territory of Indonesia are obliged to carry out what is mandated in the policy. The standardization policy for university libraries throughout Indonesia is an effort by the national library to make higher education library services of equal quality. For this reason, good university library management is needed in managing its resources effectively and efficiently, in order to produce quality university library service outputs. At this time, university libraries have developed their digital libraries using websites such as digilib, e-library, or applications that can be accessed with the help of an internet network that can be used by students, lecturers, and researchers from inside and outside the university where the library is located. They can easily access knowledge and information 
quickly and at any time only from their respective devices/devices without having to come to the library building.

Therefore, the role of librarians in the implementation of knowledge management in university libraries is important for the continuity of knowledge so that it can be explored and disseminated to knowledge and information seekers so that the functions of higher education libraries, namely education, research, information, recreation and preservation can be achieved.

Librarians have a responsibility to guide users in using digital content. This is a reality that can be found everywhere, that any institution will not develop without professional human resources, even though they have adequate facilities and infrastructure. In addition, the service of library staff is often used as a benchmark for users in assessing the quality of libraries, because in that section human resources directly interact with users. Library staff, both library technical staff and librarians as the person responsible for the implementation of services, must know this. With the obligation of the PT SNP, the IPDN library is also transformed to deal with changes in the conventional library system to an ICT-based library, this is done so that users / users at the Jatinangor IPDN library, namely praja, graduate students, lecturers and researchers can gain access to knowledge and information and even publish it .

In connection with this function, in 2004 the IPDN library received assistance from the World Bank to become an IPDN library, then in 2005, the IPDN library was upgraded to an ICT-based library although it was still in the adjustment stage, so that users could search for books and other sources of information. It is desirable to use online catalog searches, download scientific articles/works, international journals for free, read scientific papers online, and so on.

Although the IPDN library has been around for a dozen years, based on an initial interview on April 24, 2019 to the head of the library and IPDN librarian, it can be seen that there are differences in the educational background of library staff, between librarians with S-1 and S-2 educational backgrounds in Library and Information Sciences. and non-Library and Information Sciences and the low ability of library staff to use technology creates gaps/levels of knowledge, thus hampering the implementation process of knowledge management. Therefore, researchers are interested in knowing the implementation of knowledge management in IPDN ICT-based libraries, because according to researchers as an official university in government science IPDN has the advantages and uniqueness of knowledge and information so that it can be spread.

\section{RESEARCH METHODS}

\section{Research Design}

This study uses a qualitative approach, because the empirical data are in the form of words, sentences, gestures, facial expressions, charts, pictures and photos in the IPDN library, then the data is given meaning by the researcher. The research method used is a descriptive method where this study intends to analyze problems regarding the role of librarians in the implementation of knowledge management in IPDN libraries.

\section{Data Collection Technicques}

\section{Interview}

Techniques for obtaining informants in this study, researchers contact known practitioners through preliminary interviews who can recommend the right place or can formally contact parties who are directly related to the field. Informants or subjects who can provide information in research include the head of the library, librarian, library technical staff, lecturers and staff/students of IPDN Jatinangor. 


\section{Observation}

Observations were made with the intention of knowing the implementation of knowledge management management in the IPDN library.

\section{Documentation}

Documentation studies are used to collect and record the necessary data that will be used as material for conducting tests in this research. The data collection instruments are interview guides, observation sheets and document checklist sheets.

Primary data were obtained in the form of verbal or verbal words or speech and behavior from the subject (informant) related to the research focus. While secondary data comes from documents, photographs and objects that can be used as a complement to primary data. The characteristics of secondary data are in the form of writings, recordings, pictures or photographs related to the research focus.

This study uses qualitative data, including interview notes, observation notes related to the problem under study, official data in the form of documents or archives, memorandums in the data collection process. The data analysis technique used in this research is descriptive narrative. This technique refers to the opinion of Miles and Hubermen (in Satori, and Komariah, 2011) which is carried out through four stages, namely: data collection, data reduction, data

\section{RESULTS AND DISCUSSION}

Based on the results of interviews, observations and documentation of the librarian's role in the implementation of knowledge management in the IPDN library, among others: The first knowledge management process is knowledge identification. The knowledge in the library is adjusted to the works written by the lecturers, the majority of which are about government science. Lecturers write based on their educational background and teaching assignments so that they are linear with the goals of Tridharma. Furthermore, the task of library managers is to classify the works of lecturers, undergraduates and postgraduate students, including: LA/Thesis, Thesis and Dissertation according to their respective faculties. On the other hand, the technical staff of the ICT department prepares the repository as a database of scientific works for the purposes of graduation for praja and student as well as staffing of lecturers.

Determination of human resources in identifying knowledge according to their abilities such as in the field of automation, processing, service, and even ICT, after attending the training, the results will be taught to others. In identifying knowledge, librarians divide them based on primary literature and gray literature. Primary literature is the result of research through in-depth study whose publication is based on the results of a review by the experts (reviewers).

Gray literature consists of: Final Report, Thesis, Thesis, Dissertation. Furthermore, for LA and thesis not everything is included in the repository because it becomes a dilemma for librarians, when the Dikti circular must be full text, but in fact some civil servants who dare to submit the rest are only abstracts or summaries.

The second knowledge management process is knowledge acquisition. Procurement of knowledge is carried out by means of library staff participating in turnitin check training, antiplagiarism, OJS (online journal system) training and library automation training, because they will manage knowledge written in the form of scientific works from lecturers, civil servants and postgraduate students.

Lecturers or trainers usually write based on personal awareness whether it is in accordance with the courses or training subjects being taught, after which the library technical staff facilitates collaboration between writers and publishers who usually partner with IPDN 
libraries. After publication, usually library technical staff prioritize books written by lecturers to be submitted to the procurement department so that 20-50 copies can be purchased by IPDN libraries. In terms of providing knowledge in the IPDN library, librarians and technical staff in the ICT section prepare knowledge both in print and non-print based on the requests and needs of users, in addition to the results of discussions between librarians and lecturers about popular science.

The process of procuring knowledge, both printed and non-printed, is carried out by means of: library managers distributing questionnaires to lecturers and staff of any printed or non-printed materials needed to support the lecture process, or there are also their own ideas from the librarian.

Basically, technical personnel only implement whatever is needed by the users. For example, when a lecturer needs a platform for scientific work and at the same time relates to their staffing and rank, the librarian prepares the application. In addition, when undergraduate and postgraduate students need electronic journals to publish their scientific articles, the ICT library manager prepares electronic journals and subscribes to paid search engines.

Then for the management of printed books there is an OPAC / digital catalog. Previously, the IPDN library used the Senayan application for the printed book database. Meanwhile, nonprint collections use an ER (electronic resource) application and the librarian also prepares a local database that can be accessed through the website at er.ipdn.ac.idn but can only be opened in the IPDN library's local network area.

In addition, there are ebooks and electronic journals, which are obtained by means of an annual subscription such as EBSCO, Procest, Cambridge, which are managed by ICT librarians to download and submit to the ER. In addition, there is also a repository using the eprints application to store the writings of lecturers, praja (thesis/LA), employees (tutorials) for the academic community and prepared for open source.

The third knowledge management process is knowledge development. To develop the knowledge of librarians, attend trainings such as training on writing scientific papers or other training related to libraries and information technology.

After attending the training, they then practice writing scientific papers, for example, after training on writing scientific papers, they implement it by making their own scientific papers and submitting them to electronic journals from other universities and publishing them. In addition, the librarian teaches what has been obtained when participating in the training to the users. In addition, it teaches lecturers how to search for electronic books and journals, how to use turnitin and how to search digital catalogs and how to publish articles to electronic journals.

The fourth knowledge management process is the distribution and sharing of knowledge, namely through socialization, book review, publication of journal articles outside the IPDN campus and providing electronic journal applications that are open to be accessed by users both inside and outside the IPDN campus.

In addition, the librarian conducts outreach to academics and students to collect LA results, theses, theses and dissertations through an ICT-based library system to be stored and distributed through open resource applications, namely repositories and open journal systems (ejorunal.ipdn.ac.id) and literature. gray library (eprints) IPDN.

The fifth knowledge management process is the integration/storage of knowledge. Librarians develop service automation, including: borrowing, returning, extending books, final reports, making membership cards, developing OJS, developing e-books, e-journals and repositories. In collecting the final report, the librarian does not collect it directly, but the praja uploads each of his written works, and the librarian only emphasizes this as a requirement to be library-free, after that the librarian in the final report section checks for plagiarism using the turnitin application. 
This is also in accordance with the opinion of the librarian of the library-free service section, namely to get a free letter from civil servants and students must submit LA abstracts, Thesis, Thesis and Dissertations then check the turnitin to the ICT department. This is a requirement to be free of libraries after passing a plagiarism check of a maximum of $30 \%$, so you can register for a trial and even to take a diploma, you must bring proof of being free of plagiarism and free of literature.

Furthermore, in the activity of bringing together scientific papers from the final praja assignment, the librarian puts files together in one drive but still internal IPDN in the ipdn.ac.id domain, because the existing network sometimes goes up and down.

The sixth knowledge management process is knowledge storage. Printed materials in the processing section are automated so that they can be viewed in a digital catalog at the address http://elib.ipdn.ac.id/katalog . In addition, in an effort to develop e-resources, IPDN Jatinangor library librarians have subscribed to ebooks and electronic journals from EBSCO with more than 3690 ebook titles and 3240 English electronic journal titles in the categories Political Science, Social Sciences, Law, Philosophy, and others. other. This ebook and electronic journal can be accessed through the address: http://search.ebscohost.com/ throughout the IPDN network.

For users outside the IPDN network, users can enter user ID: ipdnlib and password: Libr4ry_19. With the features possessed by EBSCO, all ebooks and electronic journals that have been subscribed can be downloaded by users anywhere and anytime in pdf file format.In addition, the IPDN library has also created an e-Reader application based on a local area network where the application is used as a container for ebooks and electronic journals that have been downloaded. This application can be accessed through the IPDN local network at the address: http://er.elib.ipdn.ac.id/ . Then the library repository using the eprints application can be seen on the site http://eprints.ipdn.ac.id. This repository is for storing the writings of Lecturers, praja (thesis/LA), staff (tutorials) for the academic community and prepared for open source.

According to Probst in Hendrawan (2019: 7): "To organize and manage the knowledge of a company or organization, it is necessary to group and categorize the problems encountered in the company. Core Process Knowledge Management is categorized into 6 parts, this is intended so that the manager's role is able to optimize knowledge activities in individual areas to all areas of the organization.

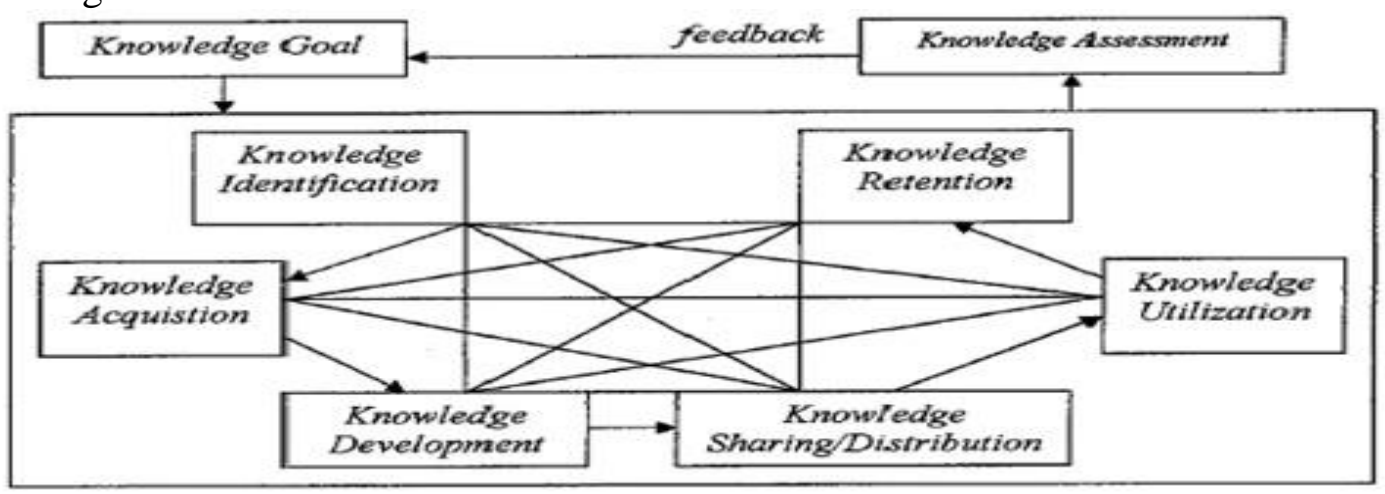

Picture 1. Core Process Knowledge Management, Probst et al (2000)

The six sections are known as Core Process Knowledge Management, this is intended by the role of the librarian to optimize Knowledge activities in the IPDN library and can be described as follows:

1) Knowledge Identification (Identification of knowledge). IPDN librarians have carried out the process of identifying knowledge, both tacit and explicit. In identifying knowledge, an 
analysis and description of knowledge is carried out in the IPDN library environment. Librarians have studied what books are needed by students and lecturers together with publishers on an ongoing basis by providing a list of user needs to determine what is needed.

2) Knowledge Acquisition (knowledge procurement). IPDN librarians have carried out this process for the educational function by procuring printed and non-printed materials. As for non-printed materials, the web section librarian prepares the supporting technology so that users can access knowledge and publish their work. Provision of government books in all its fields.

IPDN Jatinangor library collection standards have met the applicable regulatory requirements, namely the available library materials in the form of written, printed, and digital works in accordance with the applicable literature. The library materials available at the IPDN Jatinangor library consist of lecture books according to the request of the lecturer and the academia, with more than one book each. The library also provides scientific works and journal publications carried out by students (praja), lecturers and staff of IPDN Jatinangor.

Users can not only visit the IPDN Jatinangor library directly, but the library has provided library materials in digital form, namely in the form of e-books, e-journals, e-learning and discussion forums, making it easier for users to access them directly.

The fulfillment of library collections requires the procurement of library materials for IPDN Jatinangor. In the procurement of library materials, policies are carried out with input from various parties so that they are right on target. However, in an effort to improve information services, librarian efforts are needed in providing library materials that turn on the recreational function. So that visitors visit not only to complete their academic assignments but also to get other information that increases their knowledge as a refresher of knowledge.

3) Knowledge Development (knowledge development). IPDN librarians have carried out the process of building blocks where each component complements each other with Knowledge Acquisition. This stage includes all management efforts aimed at producing scientific articles that are not yet in the IPDN or which do not yet exist inside or outside the IPDN.

4) Knowledge Sharing and Distribution: The process of sharing and disseminating existing knowledge in IPDN. So that at this stage it is intended to turn isolated information and experience into something, where the knowledge can later be used for organizational progress. An important step in distributing this knowledge is to analyze the transfer of knowledge from individuals to IPDN institutions.

5) Knowledge Utilization (unification/storage of knowledge): At this stage, the librarian has stored knowledge and retrieved it as best as possible to support scientific publication activities or processes that take place within IPDN institutions.

6) Knowledge retention (storage of knowledge). In this stage, including the activities of selecting, storing and updating knowledge will be very valuable for potential problems that exist in the organization.

In terms of meeting the National Library Standards, IPDN Jatinangor library staff have met the standards, namely in the organizational structure consisting of the head of the library, librarians, ICT technical personnel and administrative staff. The number of librarians in the IPDN Jatinangor library is 15 people who have met the proper standards

minimum of 8 people $(3,711: 500$ students $=8$ people). Likewise, the technical staff has met the standard, which is more than one person for students, namely praja as many as 3,711 people. However, based on field studies, the ideal number of librarians is not proportional to the number of library service officers where the librarian doubles as a service officer. So that librarians only focus on serving users, not on developing overall services for users so that libraries can keep up with the development of science that is constantly changing. 


\section{CONCLUSION}

Librarians have implemented knowledge management in IPDN libraries, but the ideal librarian is not proportional to the number of library service officers where the librarian doubles as a service officer.

\section{REFERENCES}

Hendrawan, M. (2019). Manajemen Pengetahuan Konsep dan Praktik Berpengetahuan pada Organisasi Pembelajar. Malang: UB Press.

Sugiyono, (2016). Metode Penelitian Kombinasi. (Cet-8) Bandung: Alfabeta.

Adiprabowo, dkk (2019). Berbagi pengetahuan sebagai pembelajaran organisasi di Perpustakaan Nasional Republik Indonesia. Jurnal Kajian Informasi \& Perpustakaan Vol. 7, No. 2 (Desember 2019) 145-160 ISSN 2303-2677 (Print) ISSN 2540-9239 (Online).

Hendrawan, Muhammad Rosyihan. (2016). Leading Knowledge Management in the International Organization: the United State Agency for International Development (USAID). Record and library Journal Vol.2. No.1. January-June 2016. 